\title{
MEMAKNAI KEMBALI TRADISI WAYANG POTEHI
}

\author{
Antonius Suparno \\ Program Pascasarjana Universitas Gadjah Mada \\ email: anton_shbdg@yahoo.com
}

\begin{abstract}
Abstrak
Penelitian ini bertujuan untuk mendeskripsikan: (a) karakteristik kelisanan wayang potehi, (b) fungsi wayang potehi, dan (c) bentuk pewarisan wayang potehi sebagai akulturasi kebudayaan Indonesia dan Tiongkok. Sumber data dari berbagai karangan akademis tentang wayang potehi dan dua naskah transkripsi lakon wayang potehi berjudul Sam Hee Lam Tong dan Sie Djin Koei Tjeng See. Pengumpulan data dilakukan dengan cara: (a) studi pustaka, (b) pengamatan, dan (c) wawancara. Analisis data dilakukan dengan: (a) transkripsi data lisan, (b) pengelompokkan data, dan (c) menganalisis data dengan konsep Pementasan Finnegan, Formula Parry Lord, Fungsionalisme Malinowski, dan Transmisi Vansina. Hasil penelitian ini menunjukkan bahwa (a) keberhasilan pementasan wayang potehi didukung oleh banyak aspek pementasan, (b) wayang potehi memiliki beragam fungsi (ritual, hiburan, pendidikan, sosial, dan ekonomi), dan (c) ada beragam cara untuk mewariskan wayang potehi, namun belum efektif karena tidak semua dilakukan secara maksimal.
\end{abstract}

Kata kunci: formula, fungsi, kelisanan, pementasan, transmisi

\section{REINTERPRETING THE POTEHI PUPPET TRADITION}

\begin{abstract}
This study aims to describe: (a) the characteristics of the potehi puppet orality, (b) the functions of the potehi puppet, and (c) the transmission forms of the potehi puppet as acculturation of Indonesian and Chinese cultures. The data sources were various scientific articles on the potehi puppet and two transcripts of potehi puppet stories entitled Sam Hee Lam Tong and Sie Djin Koei Tjeng See. The data were collected through: (a) literature study, (b) observations, and (c) interviews. They were analyzed by : (a) transcribing the oral data, (b) grouping the data, and (c) analyzing data using Finnegan's staging concept, Parry Lord's formula, Malinowski's functionalism, and Vansina's transmission. The research findings indicate that: (a) the success of a potehi puppet performance is supported by many staging aspects, (b) the potehi puppet has various functions (ritual, entertainment, education, social, and economic), and (c) there are various ways to inherit the potehi puppet, but they have not been effective because not all of them are optimally applied.
\end{abstract}

Keywords: formula, functions, orality, performance, transmission

\section{PENDAHULUAN}

Wayang potehi merupakan akulturasi kebudayaan Indonesia dan Tiongkok yang telah lama hidup dan bertahan di Indonesia sejak lama. Lestari (2010: 2) bahkan menyebutkan tradisi ini telah masuk ke Indonesia sejak abad 16-19 M. Bukan waktu yang singkat. Dalam perjalanannya juga, wayang potehi telah merebut hati banyak masyarakat Nusantara karena menjadi media hiburan dan penyalur perangkat nilai-nilai kehidupan 
yang sangat berharga. Masa jaya wayang potehi kemudian mulai memudar seiring dengan diterbitkannya Inpres nomor 14 tahun 1967 yang isinya mengatur larangan pada agama, kepercayaan, dan adat istiadat Tionghoa di Indonesia (Mastuti, 2009: 69). Itu berarti wayang potehi tidak lagi dapat dipentaskan dengan bebas kepada masyarakat. Banyak dalang yang kemudian menyimpan wayang potehi dan kehilangan mata pencarian selama puluhan tahun lamanya.

Angin segar kembali bertiup bagi wayang potehi setelah Gus Dur mencabut Inpres tersebut dan memberikan kebebasan seluas-luasnya kepada masyarakat Tionghoa sebagaimana masyarakat lainnya. Para dalang kembali menggeluti profesi lamanya. Akan tetapi, kemunculan wayang potehi berhadapan dengan kenyataan bahwa masyarakat telah menikmati berbagai alternatif hiburan dan media lainnya. Wayang potehi pun perlu waktu untuk kembali dikenal sebagaimana puluhan tahun lalu. Tentunya ini menjadi tantangan sekaligus kerja keras bagi para dalang dan pencinta wayang potehi umumnya.

Ada kenyataan lebih mengejutkan, wayang potehi yang notabene berakar dari kebudayaan Tiongkok dan kepercayaan Konghucu justru dirawat oleh dalang keturunan Jawa. Masyarakat Tionghoa justru sebagian besar memilih untuk tidak terlibat secara aktif dalam pementasan wayang potehi, baik sebagai dalang maupun sebagai pemain musik. Mereka lebih memilih menjadi penanggap atau donatur pementasan. Dengan demikian, dapat dikatakan bahwa masyarakat di luar etnis Tionghoa dimanfaatkan untuk menjaga dan merawat wayang potehi.

Fakta yang terjadi di atas bukan berarti menunjukkan sikap rasis, tetapi sebagai bahan renungan bahwa masyarakat Tionghoa saja tidak mau merawat sebagai pelaku aktif wayang potehi lalu bagaimana dengan masyarakat di luar lokus kebudayaan Tionghoa. Untuk menghindari kesalahpamahan yang lebih serius lagi, dalam konteks penelitian ini, wayang potehi diposisikan sebagai bagian dari khazanah Nusantara. Hal tersebut tidak dapat dimungkiri dari fakta sejarah bahwa wayang potehi telah lama hidup dan berkembang di bumi Nusantara. Keprihatinan terhadap sekaratnya tradisi ini harus dipandang sama pentingnya dengan kekhawatiran kita pada kepunahan tradisi Nusantara yang lain. Oleh karena itu, tanggung jawab pewarisan dan pelestarian wayang potehi perlu diletakkan pada pundak masyarakat Indonesia secara umum.

Sebagai contoh konkret minimnya proses pewarisan, penulis mengambil kasus yang terjadi di Klenteng Tay Kak Sie, Semarang. Sepeninggalnya dalang Thio Tiong Gie pada Rabu, 20 Agustus 2014, tonggak wayang potehi di Klenteng Tay Kak Sie diestafet ke tangan muridnya yang bernama Bambang Sutrisno. Usianya kini tidak muda lagi. Di samping itu, dalam lingkungan keluarga, dalang Thio pun hanya berhasil mengkader 1 dari 7 putranya yang bernama Thio Hoo Lip untuk melanjutkan kariernya yang dimulai sejak usia 27 tahun itu ${ }^{1}$. Proses pewarisan setelah itu tidak lagi gencar dilakukan. Dengan demikian, dikhawatirkan ke depannya klenteng ini tidak lagi memiliki dalangnya sendiri.

Herkovitz (Lestari, (2010:16) dalam tulisannya juga melihat gejala yang sama dalam proses pewarisan. Menurutnya, generasi muda saat ini lebih tertarik pada budaya instan. Mereka tidak lagi tertarik pada panggung hiburan kebudayaan, namun bergeser ke media audio-visual. Ketidaktertarikan generasi muda terhadap hal-hal yang bersifat tradisional juga diungkapkan oleh Herkovitz ${ }^{1}$. Ketidaktertarikan tersebut didukung oleh hilangnya otoritas orangtua akibat tekanan ekonomi yang mengharuskan mereka bekerja di luar rumah dalam waktu yang panjang. 
Dengan demikian, tidak ada waktu bagi mereka untuk menjalankan tradisi yang ada.

Terdorong dari kegelisahan yang sama, Prawita (2013: 172) juga menambahkan beberapa alasan wayang potehi hanya memiliki sedikit peminat. Pertama, banyak masyarakat yang merasa bahwa pementasan wayang potehi aneh. Keanehan tersebut bisa jadi muncul karena corak pementasan wayang potehi berakar dari kebudayaan luar dan berbeda dengan hiburan populer saat ini. Kedua, banyak masyarakat yang tidak/belum mengenal karakter yang terdapat dalam lakon wayang potehi. Ketiga, mengalirnya banyak alternatif hiburan populer, banyak generasi muda yang lebih memilih menonton film dibandingkan pementasan wayang potehi. Keempat, munculnya anggapan bahwa menonton wayang potehi hanya akan menghabiskan waktu saja karena lakon wayang potehi membutuhkan waktu yang cukup lama untuk diselesaikan. Dalang Bambang Purwanto juga mengungkapkan, pementasan lakon seperti Sie Djin Koei membutuhkan waktu berbulan-bulan karena panjangnya cerita yang dibawakan².

Maskurin (2014: 172) mengungkapkan bahwa wayang potehi saat ini kurang diketahui oleh masyarakat luas, meskipun telah cukup lama bertahan di Indonesia. Akibat kurangnya pemahaman tersebut, wayang potehi tidak begitu diterima dan dihayati sebagai unsur kebudayaan yang patut diapresiasi.

Berdasarkan paparan di atas, kurangnya perhatian masyarakat terhadap seni wayang potehi menjadi isu yang penting untuk diperhatikan lebih jauh. Hilangnya tradisi wayang potehi sama dengan hilangnya tradisi Indonesia. Kehilangan wayang potehi berarti kehilangan sistem proyeksi, alat pengesahan, alat pendidikan, dan media perjuangan (lih. Insriani, 2014: 7). Untuk mempertahankannya perlu ada upaya yang nyata untuk mem- perkenalkannya kepada masyarakat.

Berdasarkan uraian para peneliti di atas, dapat dikatakan bahwa wayang potehi belum dapat diterima oleh masyarakat secara umum karena mereka belum mengenal dan menggali lebih dalam. Oleh sebab itu, penelitian ini secara khusus mengangkat mengenai kelisanan, fungsi, dan sekaligus menawarkan bentuk pewarisan yang dapat diambil untuk mempertahankan wayang potehi. Ketiga hal tersebut belum dibahas secara khusus oleh berbagai peneliti sebelumnya. Kehadiran tulisan ini dapat membantu masyarakat untuk memaknai serta memahami wayang potehi sekaligus memiliki cara untuk melestarikan dan mewariskannya.

Kelisanan menjadi persoalan pertama yang bahas karena mengungkapkan secara lebih dalam substansi wayang potehi sebagai sebuah tradisi lisan. Persoalan fungsi juga dianggap perlu karena sebuah tradisi akan dihidupi oleh masyarakat kalau tradisi tersebut dapat memuaskan naluri manusia (lih. Koentjaraningrat: 1987: 171; Baal, 1988: 51). Kemudian persoalan mengenai langkah pewarisan menjadi isu yang paling strategis untuk menanggapi secara langsung dan praktis persoalan eksistensi wayang potehi yang hari ini berada di ambang kemerosotan.

\section{METODE}

Penelitian ini dilakukan di Kampung Pecinan, Semarang Tengah, Jawa Tengah dengan fokus penelitian pementasan di Klenteng Tay Kak Sie gang Lombok. Informasi mengenai wayang potehi diperoleh dari 15 responden yang kompatibel dengan jangkauan usia dan profesi yang berbeda. Ada yang merupakan dalang, pemain musik, budayawan, pemerintah setempat, dan pengamat wayang potehi.

Data-data yang ada dianalisis dengan metode deskriptif kualitatif seperti berikut. Informasi-informasi berbahasa Hokkian dan Jawa ditranskripsikan ke dalam bahasa Indonesia dengan menggu- 
nakan model penerjemahan bebas dengan tetap memperhatikan makna leksikal dan makna konotatif sesuai dengan konteks. Selanjutnya data secara keseluruhan dikelompokkan sesuai dengan kebutuhan data dalam masalah penelitian. Data yang telah dikategorikan dianalisis dengan menggunakan dua paradigma, yaitu paradigma struktural dan fungsional. Paradigma struktural digunakan untuk memahami konteks pementasan dan produksi tradisi lisan. Konsep yang digunakan untuk menganalisis aspek pementasan adalah konsep pementasan Finnegan. Selanjutnya untuk menganalisis aspek produksi lakon wayang potehi, digunakan teori Formula Parry-Lord guna menemukan formula yang terdapat dalam lakon wayang potehi sebagai stock on trade bagi para dalang. Paradigma fungsional digunakan untuk melihat wayang potehi dari segi fungsi yang ditawarkan bagi masyarakat. Fungsi inilah yang kemudian diyakini dapat menawarkan daya tarik bagi masyarakat.

\section{HASIL DAN PEMBAHASAN Kelisanan dan Fungsi Wayang Potehi}

Persoalan kelisanan tidak akan pernah lepas dari pementasan. Kelisanan dapat mewujud dalam pementasan. Hal ini senada dengan apa yang disampaikan Sunarti (2007:40-41) bahwa sebuah pementasan hanyalah peristiwa yang hanya terjadi dalam satu kali pementasan. Meskipun pementasan diulang di tempat yang sama dengan pemain yang sama, pertunjukkan tersebut akan selalu baru karena muncul dari proses produksi secara spontan. Pementasan yang sama selalu akan kembali dilantunkan/dipertunjukkan, tetapi hakikatnya berbeda. Bisa ditarik jauh sebelumnya juga disampaikan oleh Finnegan (1992: 86) bahwa "performance is in a sense perhaps an element in every action".

Pementasan wayang potehi bisa dilakukan di mana saja, asal tersedia ruang yang cukup untuk mendirikan panggung dan menampung penonton. Di Pecinan Semarang, pementasan wayang potehi seringkali digelar di depan klenteng. Salah satu tempat pementasan wayang potehi adalah klenteng Tay Kak Sie. Dengan kata lain, hampir tidak pernah dilakukan di dalam gedung. Dengan memilih ruang terbuka seperti halaman klenteng, penonton akan lebih leluasa menikmati jalannya pertunjukan. Sesekali pementasan dilakukan di tengah jalan raya kawasan Pecinan, Semarang dalam rangka memeriahkan tahun baru Cina atau Imlek.

Berkaitan dengan konteks tempat, klenteng Tay Kak Sie memang telah sering dijadikan pusat pementasan beragam pertunjukkan kebudayaan, termasuk pementasan wayang potehi. Klenteng ini merupakan klenteng Budha yang terletak di Gang Lombok. Cikal bakal klenteng Tay Kak Sie adalah klenteng yang didirikan oleh masyarakat Cina di Pecinan Lor dan Pecinan Kulon, yaitu klenteng Kwan Im Ting yang didirikan pada tahun 1746 . Oleh karena terjadi kerusuhan masyarakat di sekitar klenteng pada tahun 1753 dan lokasi klenteng yang dianggap tidak memadai, maka pada tahun 1771 klenteng dipindahkan ke lokasi di pinggir kali Semarang yang berupa kebun lombok yang luas. Tempat ini dikenal masyarakat sebagai Gang Lombok. Klenteng Tay Kak Sie selesai dibangun tahun 1772 . Arti nama Tay Kak Sie adalah Kuil/Klenteng Kesadaran Agung 3 .

Pementasan wayang potehi menggunakan panggung kecil yang terbuat dari bahan kayu dalam bentuk rumah mini. Di dalam bilik rumah kecil tersebut terdapat alat musik, dalang, dan pemain musik. Seluruh alat-alat yang mendukung pementasan, semuanya berada di dalam ruang panggung tersebut. Sementara, penonton berada di bagian depan panggung. Penonton akan menyaksikan pentas di atas panggung yang berukuran sekitar 
$3 \times 4$ meter dan ketinggian kurang lebih 1,5 meter. Penonton dapat mengambil posisi sesuai yang diinginkan di depan panggung.

Selain tempat, waktu juga merupakan hal yang sangat penting dalam pementasan wayang potehi. Penentuan waktu pementasan wayang potehi sangat tergantung pada pihak yang mengadakan acara. Pada zaman dulu, tradisi pementasan wayang potehi di Klenteng Tay Kak Sie dilaksanakan dengan jangka waktu yang cukup panjang sebagaimana wayang kulit. Akan tetapi, dalam perkembangannya sekarang ini, pertunjukan wayang potehi dilaksanakan dalam waktu relatif singkat, yakni dua jam dalam satu kali pementasan. Dua jam pada sore hari, yaitu 15.00-17.00 dan malam 19.00-21.00 (Prawita, 2013: 4). Lakon cerita yang dibawakan bisa sama atau pun berbeda. Tergantung permintaan penanggap, penonton, atau keputusan dalang. Apalagi pada saat perayaan besar seperti Imlek dan perayaan hari ulang tahun kedatangan Laksamana Cheng Ho di kota Semarang.

Pecinan Semarang memiliki dua nama dalang yang sering pentas di depan Klenteng Tay Kak Sie. Kedua dalang tersebut, yaitu dalang Thio Tiong Gie dan dalang Bambang Sutrisno. Dalang Thio Thiong Gie atau juga bisa dipanggil Teguh Candra Irawan merupakan dalang senior di Pecinan Semarang sekaligus orang yang membawa tradisi pementasan wayang potehi masuk ke Semarang dan Pecinan secara khusus. Ia mulai mementas wayang potehi sejak usia 27 tahun di Cianjur pada tahun 1958 setelah belajar wayang potehi secara otodidak. Bambang Sutrisno merupakan murid dalang Thio yang selalu membantunya dalam berbagai perhelatan pentas wayang potehi.

Ketiga dalang ini juga pernah mengalami pengalaman sabotase kebudayaan pada masa Soeharto. Mereka serta dalang lainnya mengalami kehilangan pekerjaan selama lebih dari 30 tahun. Kebanyakan dari mereka kemudian memilih untuk mengambil profesi lain guna memenuhi kebutuhan hidup sehari-hari. Kebebasan untuk kembali mendalang lagi diperoleh kembali pada masa Gus Dur. Banyak pementasan kembali digelar di berbagai perhelatan tanpa khawatir lagi dengan pemerintah dan aparat-aparat keamanannya.

Sebagian besar dalang wayang potehi menggantungkan diri mereka secara ekonomi untuk memenuhi kebutuhan kelurga. Dalam hal ini, wayang potehi memiliki fungsi ekonomi yang dapat memberikan profit bagi para dalang maupun para pemain musik. Akan tetapi, pada kenyataannya memang penghasilan yang diperoleh para dalang dalam setiap kali pementasan tidaklah mencukupi. Dalang Bambang Purwanto menyebutkan bahwa dalam satu hari, mereka biasa dibayar sekitar Rp1.500.000. Itupun masih harus dibagi kepada kru pementasan lainnya yang berjumlah sekitar 5-6 orang ${ }^{4}$. Dengan demikian, secara ekonomis, para dalang wayang potehi hari ini masih mengalami kesulitan secara ekonomi. Biaya yang ada tentu tidak akan cukup untuk memenuhi kebutuhan keluarga, apalagi jika dialokasikan untuk perawatan wayang potehi.

Pementasan wayang potehi biasanya disaksikan oleh penonton yang jumlahnya tidak selalu menentu. Terkadang cukup banyak, terkadang juga sangat sedikit atau bahkan tidak ada sama sekali. Menurut pengakuan dalang Bambang Sutrisno, sekalipun penonton tidak ada, jika pementasan wayang potehi ditujukan untuk kepentingan ritual maka pementasan tersebut akan tetap dilakukan ${ }^{5}$. Hal tersebut terjadi karena pementasan tersebut diyakini oleh para potehiwan sedang disaksikan langsung oleh para dewa.

Para penonton pementasan wayang potehi berasal dari berbagai usia, strata sosial, jenis kelamin, agama, dan kebudayaan. Mereka bukan hanya orang 
Tionghoa, tetapi juga keturunan Jawa. Dalam hal ini, wayang potehi berfungsi sebagai pemersatu berbagai kalangan sosial masyarakat. Tidak ada sekat-sekat yang membatasi satu dengan lainnya. Di samping itu, penonton yang ada juga disuguhi oleh barbagai nilai-nilai moral dan pendidikan melalui lakon yang dipentaskan.

Berdasarkan pengakuan penonton, ditemukan bahwa ada beberapa motivasi yang mendorong penonton potehi untuk datang di acara pementasan wayang potehi, yaitu (1) adanya keterkaitan dengan pementasan wayang potehi sebagai bagian dari ritual di klenteng, (2) adanya keinginan untuk mendengarkan berbagai lakon yang diceritakan, dan (3) sebagai ajang wisatawan rohani. Sementara pekerjaan dari para penonton sangat bervariatif, yaitu (1) pedagang, (2) buruh pabrik, (3) penjaga klenteng sendiri, dan (4) mereka yang secara kebetulan hadir di daerah Pecinan Semarang. Di samping itu, beberapa pegawai pemerintah juga hadir, terutama yang berasal dari keturunan Tionghoa yang bekerja sebagai pegawai negeri.

Pementasan wayang potehi di Klenteng Tay Kak Sie, Semarang membutuhkan beberapa jenis alat musik, antara lain gembreng besar (tai loo), gembreng kecil (siauw loo), gendang (tong ko), kecer besar (toa poa), piak ko, kecer kecil (sio poa), kenong, gong kecil (sio loo), rebab (hian $n a)$, bende (twalo), seruling (bien siauw), terompet (thua jwee), erhu (sejenis rebab), dan cinghu (sejenis rebab kecil). Semua alat musik tersebut menghasilkan bunyibunyian yang mendukung kelancaran pementasan wayang potehi dan dimainkan oleh sekitar 3-4 orang saja.

Berdasarkan irama yang dihasilkan, alat-alat musik yang di atas tergolong ke dalam dua jenis, yaitu melodis dan perkusif. Alat musik yang dikategorikan melodis tentunya dapat menghasilkan suara yang memiliki notasi tertentu, se- perti seruling, erhu, cinghu, dan terompet. Sedangkan alat musik perkusif ialah alat musik yang menghasilkan variasi suara ketukan sebagai hasil dari resonansi seperti gembreng, gendang, kecer, bende (twalo), dan kenong. Keduanya dapat dimainkan secara kolaboratif/komplemen sesuai dengan kebutuhan pementasan.

Sebagai salah satu unsur pertunjukkan, musik memiliki peranan yang cukup penting dalam pementasan wayang potehi. Kehadiran musik menjadi penegas sekaligus pendukung yang membantu dalang maupun penonton untuk memainkan dan memaknai cerita yang dibawakan. Itulah sebabnya, sebuah kelompok pementasan wayang potehi selalu memiliki kru musik yang siap untuk mengisi musik pengiring pada beberapa bagian tertentu saat pementasan. Akan tetapi, Djohan memiliki pendapat yang berbeda mengenai istilah "musik pengiring" dalam pementasan wayang potehi. Menurutnya, bunyi yang dihasilkan dari alat musik dalam pementasan wayang potehi tidak selalu dikategorikan musik. Sebuah bunyi-bunyian baru dapat disebut sebagai musik apabila tersusun atas notasi-notasi tertentu. Jika tidak menghasilkan notasi, maka bunyibunyian yang dihasilkan hanyalah berupa bunyi-bunyian . Untuk itu, istilah "variasi bunyi" dapat digunakan untuk menyebutkan dua kategori bunyi-bunyian di $\operatorname{atas}^{6}$ (perkusif dan melodis).

Di dalam proses produksi variasi bunyi, ada unsur-unsur lebih kecil yang sebenarnya mendukung penciptaan suasana. Unsur-unsur tersebut adalah tempo dan volume. Semakin lambat atau cepatnya tempo akan menciptakan rasa dan emosi yang berbeda. Jika tempo dari variasi bunyi yang dimainkan semakin cepat, maka variasi bunyi tersebut menunjukkan rasa gembira, marah, dan peperangan. Sebaliknya jika tempo semakin lambat, maka akan menunjukkan suasana romantis, kemolekan, kesedih, kekecewa, keputusasaan, dan sebagainya. Contohnya, 
pada saat seorang putri secantik Law Kim Teng dalam lakon Sie Djin Koei Tjeng See memasuki pentas dan pemusik ingin menggambarkan kemolekan Law Kim Teng. Tempo dari variasi yang dibawakan tentunya lebih lambat. Berbeda dengan adegan penyerangan pasukan Tong Tiauw di kota Lou Hoa Kwan dalam lakon yang sama. Tempo yang digunakan lebih cepat dan menggebu. Penjelasan mengenai tempo demikian halnya juga dengan volume. Semakin keras volume maka tercipta suasana yang tegang, amarah, ketakutan, dan keperkasaan. Sementara itu, semakin kecil volume menunjukkan suasana keharmonisan, kemolekan, keromantisan, kesedihan, dan kegundahan.

Tokoh-tokoh yang biasanya muncul di dalam pementasan wayang potehi cukup beragam. Tokoh-tokoh tersebut selalu dilekati dengan status sosial dan jabatan. Oleh karena lakon pementasan wayang potehi biasa berupa cerita-cerita kerajaaan, maka biasanya tokoh-tokoh yang terlibat antara lain, raja, raja muda, penasehat raja yang baik, penasehat raja yang jahat, permaisuri, perdana menteri, pendekar/ksatria, jenderal perang, panglima perang, prajurit, pangdam, lurah, walikota, dan masyarakat biasa. Di samping itu, lakon pementasan wayang potehi juga biasanya melibatkan para dewa, murid para dewa, malaikat, dan siluman. Setiap tokoh memiliki keistimewaan dan fungsinya masing-masing.

Setiap tokoh di atas memiliki kostum yang khas dengan motif, warna, dan aksesoris yang berlatarbelakangkan kebudayaan Tiongkok. Kostum wayang potehi terdiri dari pakaian, penutup kepala, dan senjata. Kostum tersebut tersebut terdiri dari motif, garis, warna, dan bidang yang selanjutnya disesuaikan dengan karakter dan jabatan dari tokoh yang menggunakannya. Kostum tersebut dikenakan pada wayang potehi yang terdiri dari kepala, kaki, tangan, dan sepatu. Tingginya 30 $\mathrm{cm}$ dan lebarnya, $15 \mathrm{~cm}$. Ukurang kepala- nya kurang-lebih $5 \mathrm{~cm}$. Kayu merupakan bahan bahan dasar dari kepala, kaki, dan tangan. Sementara baju dibuat dari kain blacu (Prawita, 2013: 4).

Dalam pementasan wayang potehi, ekspresi tokoh-tokoh dimainkan oleh sang dalang melalui gerakan-gerakan yang teratur dan ditafsirkan oleh dalang sendiri. Gerakan-gerakan jari tangan yang menggerakkan tokoh-tokoh wayang dalam pementasan wayang potehi, menentukan aspek keserasian gerakan jari tangan dengan variasi bunyi yang mengiringinya. Untuk mendukung berbagai gerakan tokoh yang ada di dalam pentas, maka kekuatan dalang adalah kemampuan ia menirukaan suara perempuan, suara burung, dan suara-suara lainya yang ada di dalam berbagai karakter yang ada pada tokoh wayang potehi. Seorang dalang wayang potehi, harus memahami kostum tokoh, sehingga mereka mampu memberikan irama dan karakter itu akan berhubungan dengan musik dan suara yang dimainkan oleh dalang.

Berbagai aspek pementasan di atas pada akhirnya akan membawa penonton pada suatu permenungan mengenai kehidupan. Sebagaimana lakon-lakon pewayangan pada umumnya, akhir dari cerita akan mengarah kepada suatu kesimpulan yang sarat akan nilai-nilai pendidikan karakter. Para penonton dapat memetik pengalaman dari cerita yang disaksikan tersebut dan mengaplikasikannya dalam kehidupan keseharian.

\section{Formula Wayang Potehi (Perspektif Parry-Lord)}

Dalam paparan di atas, telah disampaikan berbagai unsur yang mendukung suatu pementasan wayang potehi. Pada bagian ini, akan dijelaskan salah satu metode yang digunakan oleh para dalang untuk memproduksi sebuah lakon yang panjang tanpa bergantung pada naskah. Berdasarkan penelitian, para dalang tersebut menggunakan apa yang disebut oleh 
Lord sebagai "formula" untuk menguasai sebuah lakon. Menurut Lord (1976: 30); Udu (2016: 37), formula merupakan kelompok kata yang secara teratur dimanfaatkan dalam kondisi matra yang sama untuk mengungkapkan satu ide hakiki (pokok). Dalam penulisan mengenai konsep formula berdasarkan perspektif Parry-Lord berarti mengungkapkan 3 hal penting, yaitu a) formula epitheton, b) ungkapan formulaik, c) tema/kelompok gagasan (Taum, 2011: 100).

\section{a. Formula Epitheton}

Epitheton mengandung pengertian 'kata sifat atau klausa yang berfungsi sebagai kata sifat yang memerikan ciri khas seseorang atau suatu benda' (Taum, 2011: 102). Penggunaan epitheton tokoh/benda dalam pementasan wayang potehi dapat ditemukan pada beberapa pemerian ciri khas terhadap tokoh-tokoh ataupun benda yang terdapat dalam lakon wayang potehi. Epitheton tokoh yang berhubungan dengan nama tokoh, digunakan untuk mengingat jabatan, gelar, dan karakter tokoh dalam lakon. Sedangkan epitheton benda digunakan untuk menjelaskan dan menggambarkan suatu benda. Berikut ini merupakan contoh epitheton tokoh untuk menunjukkan karakter, gelar, dan jabatan tokoh yang terdapat dalam lakon Sam Hee Lam Tong dan Sie Djin Koei Tjeng See.

Raja THIO KONG IN perintah adiknya nama THIO KHONG GIE untuk menggantikannya sementara. Setelah itu raja menuju ke TJIA YA KONG ketemu THIO TAY HOUW untuk minta restu mau serang LAM TONG. Sebetulnya TAY HOUW tidak setuju karena bermimpi THIO KONG IN jatuh dari pohon LIOE TJOE dan selamat ditolong oleh 5 ekor burung HONG. Tapi THIO KONG IN memaksa, akhirnya TAY HAUW izinkan pada THIO KONG IN (Soetrisno, 1968: 2).
“THIO KONG IN" merupakan nama dari raja kerajaan TAY SONG TIAUW. Mendengar nama tersebut, referen seorang dalang ataupun penonton yang telah mendengar cerita Sam Hee Lam Tong langsung terarah kepada seorang raja yang berwajah merah, angkuh, dan seorang pembunuh. Nama tersebut menjadi sebuah epitheton tokoh karena dapat memerikan ciri khas dari tokoh raja dari dinasti Song, kerajaan yang membawahi beberapa kerajaan kecil. Dalam penceritaan kisah Sam Hee Lam Tong, THIO KONG IN menjadi sebuah formula yang pasti disebutkan/diceritakan secara intens dalam alur lakon.

Besok pagi HOAN LEE HWA pimpin sekalian pasukan mulai gempur barisan musuh. HOAN LEE HWA beserta pasukannya mulai masuk ke dalam itu barisan dan HOAN LEE HWA membuka itu wasiat HOUW-LOUW dibuka tutupnya hingga keluar naga yang bisa keluar/menyemburkan air sampai api di dalam barisan bisa padam. Barisan tersebut telah bisa diobrak-abrik oleh HOAN LEE HWA hingga pasukan dari TJOE TING SAN terdesak bahkan TJOE TING SAN terbang dicegat CIN HAN lari masuk bumi dicegat OUW IT HOUW (Waluyo, 2001: 29).

HOUW-LOUW merupakan wasiat yang merujuk pada buli-buli yang memiliki isi. Dalam kutipan di atas, digambarkan bahwa HOU LOUW milik HOAN LEE HWA berisi naga yang dapat menyemburkan air. Wasiat tersebut menjadi milik HOAN LEE HWA dan bukan milik tokoh SIE TENG SAN atau TOUW IT HOUW. Jika memang tokoh tertentu membutuhkan wasiat tambahan yang tidak dimilikinya maka tokoh tersebut dapat meminjam wasiat milik tokoh lainnya. Benda ataupun wasiat di atas selalu berkenaan dengan tokoh tertentu dengan fungsi dan tujuannya. Benda tersebut akan selalu 
disebutkan dalam setiap kali penceritaan dalam ruang yang memungkinkan benda/ wasiat tersebut hadir.

\section{b. Ungkapan Formulaik}

Ungkapan formulaik merupakan larik atau separuh larik yang disusun berdasarkan formula (Lord, 1976: 47). Ungkapanungkapan formulaik seringkali diulangulang dalam sebuh korpus kebudayaan. Formula-formula yang ada dipakai dalam sebuah larik atau sajak-sajak berdasarkan sebuah konvensi yang telah disiapkan oleh tradisi tempat karya tersebut muncul. Dengan demikian, ungkapan-ungkapan formulaik yang ada bisa jadi telah dikenal oleh kalangan masyarakat tempat karya tersebut muncul dan sekaligus mewakili gagasan dan horizon harapan penikmat karya. Berikut ini merupakan ungkapan formulaik dalam lakon Sam Hee Lam Tong. Oleh karena ungkapan formulaik biasanya tersaji dalam bentuk larik/baris, maka untuk mempermudah dikaitkan dengan arti dalam bahasa Indonesia maka setiap larik akan diberi nomor.

1. Yoe lay pian kee tjoe lan hang

2. Ong kie thian tijong tjay to pang

3. Ko hie tiong liang tiang kie hoe

4. Kok sin siang sioe to song kang Artinya:

1. Perkara lain-lain negeri mau dibikin takluk ada susah

2. Kerajaan sampai ke negeri Tan

3. Sungguh beruntung boleh dibilang banyak orang setia bantu membela

4. Memegang kerajaan ini sampai ke sungai Song Hong

(Soetrisno, 1950: 56-57).

Ungkapan di atas merupakan syairan atau peran yang disampaikan oleh dewa TAN POK LO TJO kepada raja THIO KONG IN setelah perang panjang yang dilaluinya. Syairan tersebut kemudian menjadi ungkapan formulaik karena terangkai dari formula-formula yang tersedia. Rangkaian itu biasanya dihafal sehingga dapat kembali disebutkan dalam berbagai pementasan Sam Hee Lam Tong. Apalagi jika ungkapan di atas sekaligus mengandung konsep nilai yang diterima oleh masyarakat umum sebagai konsep moral.

\section{c. Tema/Kumpulan Gagasan}

Formula epitheton di atas masuk dalam tataran struktur formal dan struktur sintaksis karena bertolak dari klausa ataupun unsur penyusun klausa. Akan tetapi, formula bukan hanya dalam tataran itu saja. Formula juga mencakup tataran semantik. Dalam kajian naratif, ParryLord menemukan bahwa ada kelompok gagasan yang secara teratur digunakan dalam penceritaan sebuah tradisi lisan. Lord menyebut kelompok-kelompok gagasan tersebut sebagai tema-tema atau 'themes' (Taum, 2011: 103). Istilah 'tematema' yang digunakan oleh Lord dapat diartikan sebagai kelompok ide siap pakai (stock in trade).

Dalam suatu lakon tertentu, terdapat banyak tema. Untuk mengungkapkan tema-tema yang terdapat dalam sebuah tradisi lisan, seorang penulis harus membandingkan versi-versi cerita yang sama ataupun beberapa cerita yang berbeda untuk menunjukkan adegan-adegan siap pakai ataupun deskripsi bagian-bagian cerita yang siap pakai (Taum, 2011: 104).

Berdasarkan dua naskah yang dipakai oleh penulis untuk dianalisis (Sam Hee Lam Tong dan Sie Djin Koei Tjeng See), terdapat beberapa tema yang memiliki kemiripan. Tema-tema itu sudah tentu digunakan sebagai sarana untuk meneruskan sistem nilai atau unsurunsur didaktik sesuai dengan pandangan dunia konvensional dan dibangun di atas berbagai sekuen. Tema-tema tersebut antara lain, 1) peperangan antar kerajaan karena motif dendam dan keserakahan; 2) keterlibatan dewa dalam persoalan manusia; 3) perjodohan dua orang yang saling bermusuhan; 4) pencurian senjata 
lawan sebagai strategi perang; 5) penyesalan setelah peperangan berakhir; dan 6) apresiasi raja kepada pihak yang berjasa selama perang.

\section{Proses Pewarisan}

Pewarisan merupakan langkah yang strategis untuk menjaga kebertahanan suatu kebudayaan. Jika wayang potehi hari ini dipandang sebagai tradisi yang akan punah, maka jalur-jalur pewarisan harus dipersiapkan dengan baik. Generasi tua perlu untuk menyiapkan generasi muda agar dapat melanjutkan mata rantai kebudayaan tetap terjaga dan terpelihara dengan baik. Pokok inilah yang disebut oleh Vansina (1973: 30) sebagai transmisi/ pewarisan.

Penelitian ini menawarkan beberapa bentuk pewarisan yang dapat dilakukan oleh para dalang maupun pemusik wayang potehi, pemerintah, masyarakat ataupun melalui kerja sama ketiga elemen tersebut. Sinergi tersebut diharapkan dapat membawa suatu perubahan cara pandang masyarakat, khususnya masyarakat Tionghoa dan masyarakat Indonesia umumnya.

Salah satu kemampuan yang perlu dimiliki oleh calon dalang muda adalah memahami lakon-lakon wayang potehi yang relatif panjang dan beragam. Setiap lakon tersebut tentunya memiliki serangkaian formula yang dapat membantu dalang untuk mengingat dan menguraikan kembali lakon tersebut pada saat pementasan. Akan tetapi, konsep formula di atas tentunya tidak diterima begitu saja oleh para calon dalang dan dikuasai dalam waktu yang singkat melalui serangkaian pendidikan formal.

Sejauh ini, dalang Thio Tiong Gie, Bambang Sutrisno, maupun Slamet menguasai lakon wayang potehi melalui proses internalisasi yang berulang-ulang. Proses tersebut kemudian akan muncul secara intuitif ketika mereka mulai mendalang. Dengan demikian, tidak menutup kemungkinan bahwa mereka bisa saja berimprovisasi terhadap isi lakon pementasan dengan tetap berpegang pada formula yang telah ada di dalam pemahaman mereka.

Hal ini pula yang terjadi pula pada penyair Yugoslavia (guslar) kepada murid-muridnya sebagaimana yang telah diteliti oleh Parry dan Lord. Akan tetapi, murid-murid tersebut melalui seperti sistem pendidikan "formal". Masa berguru tersebut berlangsung sekitar 3 tahun lamanya, waktu yang diharapkan seorang murid mampu menyanyikan sebuah cerita secara utuh. Para penyair biasanya akan mengajak muridnya untuk pentas dan para murid biasanya akan mendapat kesempatan untuk melanjutkan cerita selama beberapa menit ketiga gurunya beristirahat (Taum, 2011:108).

Untuk melestarikan kekuatan budaya dan fungsi tradisi lisan wayang potehi, masyarakat dan Pemerintah Kota Semarang sebaiknya aktif mentradisikan pementasan wayang potehi di berbagai peristiwa budaya yang gelar masyarakat maupun pemerintah. Pemerintah dapat menggalakkan pementasan wayang potehi, misalnya dengan menghadirkan pementasan wayang potehi sebagai pembuka dan penutup acara tertentu atau mengisi hiburan di saat acara rehat. Dengan demikian, wayang potehi dan dalang akan kembali memperoleh pengakuan di tengah-tengah masyarakat. Pementasan wayang potehi oleh pemerintah juga akan berdampak pada sikap masyarakat terhadap tradisi lisan ini. Sikap yang menilai wayang potehi sebagai tradisi kuno atau tidak sesuai dengan zaman kekinian akan berkurang seiring dengan keberpihakan pemerintah terhadap pelestarian dan pengembangan wayang potehi.

Keberpihakan pemerintah di sini dipahami sebagai bentuk dukungan (perhatian) pemerintah terhadap penguatan dan pengembangan wayang potehi. Pemerintah setempat melalui dinas-dinas 
terkait dapat menciptakan programprogram yang berpotensi melindungi dan mengembangkan tradisi lisan wayang potehi. Program-program tersebut antara lain, 1) apresiasi/penghargaan berupa pemberian insentif yang layak kepada para dalang, 2) dukungan sarana dan prasarana pementasan, 3) pewarisan melalui pelatihan-pelatihan penciptaan dan pementasan wayang potehi bagi para pelajar oleh para dalang senior, dan (4) festival wayang potehi skala lokal, nasional, dan bila perlu internasional sebagai upaya mengukuhkan posisi masyarakat Pecinan sebagai pusat pengembangan wayang potehi.

Pemerintah bisa memfasilitasi kaderisasi dan peningkatan profesionalisme dalang dengan dua cara, yaitu melalui jalur pendidikan formal ataupun secara tradisional. Secara formal, kaderisasi dalang dilakukan di lembaga-lembaga pendidikan dengan memiliki standar kurikulum tertentu dan dapat terukur. Di samping itu, kaderisasi secara tradisional dapat dilakukan dengan masuk dalam kehidupan para dalang dan mengikuti aktivitasnya sehari-hari, baik di rumah maupun pada saat pementasan. Para calon dalang tersebut bisa saja berasal dari lingkungan keluarga dalang sendiri, maupun dari luar lingkungan keluarganya. Model kedua inilah yang biasa dipakai para dalang karena bukan saja menumbuhkan pengetahuan, tetapi juga memupuk rasa di dalam hati.

Melalui kerja sama dengan pemerintah juga, para praktisi wayang potehi dapat mengupayakan kegiatan festival wayang potehi dalam skala yang luas. Festival wayang potehi belum pernah dilakukan oleh pihak manapun. Pelaksanaan festival bertujuan untuk memberi ruang bagi para pelaku budaya tradisional tersebut untuk terlibat dalam sebuah event yang besar. Kedua, mengidentifikasi keberadaan para dalang wayang potehi di suatu wilayah untuk mengetahui posisi tradisi lisan wayang potehi apakah masih digeluti oleh banyak kalangan atau telah berada dalam kondisi terancam punah. Ketiga, meningkatkan prestise tradisi lisan wayang potehi di tengah berbagai hiburan lain. Usaha meningkatkan prestise ini sekaligus untuk meningkatkan sikap positif masyarakat terutama generasi muda terhadap wayang potehi.

Sejauh ini, Pecinan Semarang belum memiliki komunitas/paguyuban yang bergerak untuk menghimpun para dalang dan pemain musik wayang potehi. Para dalang dan pemain musik justru bergerak sendiri-sendiri untuk tetap eksis. Tidak adanya wadah yang dapat menghimpun para pelaku aktif pementasan wayang potehi disebabkan karena jumlah dalang wayang potehi di Pecinan Semarang yang cukup terbatas. Padahal adanya komunitas/paguyuban tersebut cukup positif untuk melestarikan wayang potehi. Pada komunitas/paguyuban itulah para dalang dapat saling memberikan dukungan dan semangat satu sama lain sekaligus menjadi tempat pengkaderan para calon dalang sebagaimana sanggar-sanggar seni pada umumnya. Adanya komunitas/paguyuban wayang potehi juga bisa dimanfaatkan oleh para dalang untuk melebarkan sayap kerja sama sekaligus memperjuangkan wayang potehi agar mendapat pengakuan serta sokongan moral dan finansial dari pemerintah maupun masyarakat pada umumnya. Barangkali aktivitas komunitas/paguyuban yang ada di Jawa Timur menjadi gambaran bagaimana pentingnya komunitas/ paguyuban sebagai salah satu cara melestarikan wayang potehi.

Pelestarian wayang potehi di Pecinan Semarang juga dipengaruhi keinginan masyarakat pemiliknya untuk menjadikan wayang potehi sebagai tontonan yang menarik. Inovasi dari pertunjukkan wayang potehi harus mengikuti perkembangan zaman. Zaman terus berubah, demikian pula wayang potehi harus berkembang 
mengikuti zaman yang ada tanpa kehilangan rohnya. Kebudayaan perlu untuk berinovasi agar memikat generasi penerusnya. Artinya, pementasan wayang potehi harus mampu memikat generasi. Cara yang dapat dilakukaan adalah menyesuaikan kemasan, tema-tema yang relevan dengan kehidupan zaman sekarang.

Inovasi yang disebutkan bukan berarti mengarah pada penghapusan substansi wayang potehi yang terkadung atau dimaksudkan sejak kemunculannya. Sentuhan corak Tionghoa pada dekorasi, kostum, dan musik harus tetap dipertahankan. Inovasi yang dimaksudkan ialah untuk menambahkan atau memodifikasi apa yang telah ada tersebut tanpa menghilangkan nilai di balik wayang potehi. Tema-tema yang diangkat bisa dikemas secara modern dengan menghadirkan konflik tertentu atau memunculkan tokoh populer tertentu di dalam cerita. Akhir dari cerita tidak boleh diganti agar tujuan yang ingin dicapai dari sebuah lakon dapat tetap tercapai.

Inovasi pada wayang potehi juga bisa disesuaikan dengan perkembangan media populer saat ini. Media populer menjadi sasaran yang baik demi mengembangkan wayang potehi karena memiliki fungsi sebagai saluran pembudayaan yang praktis dan saluran pendidikan massa yang memiliki cakupan penikmat yang cukup luas tanpa batasan sosial. Dampak timbalbalik media terhadap seni tradisi, yaitu suatu seni tradisi kembali dikenang oleh masyarakat walaupun tradisi itu telah lama ditinggalkan masyarakat pendukungnya. Dengan adanya media, tradisi yang hampir tidak terdengar lagi dapat diperdengarkan kembali. Seperti halnya wayang potehi, keberadaan media populer tidak selamanya berdampak negatif bagi tradisi lisan tersebut. Akan tetapi, di sisi lain memberikan nilai positif dalam hal proses pewarisannya.
Pementasan wayang potehi juga dapat didokumentasikan dan diarsipkan dalam bentuk compact disc (CD) atau soft file. Dengan begitu, momen pementasan wayang potehi dapat disimpan dan dapat kembali diputar untuk berbagai kepentingan. Hasil rekaman tersebut yang kemudian dapat diputar di media populer seperti televisi maupun media sosial lainnya. Tersebarnya rekaman tersebut secara lebih luas membuat sebagian masyarakat memahami dan mengenal lebih dekat tradisi lisan wayang potehi. Setelah masyarakat mengenal dan memahami tentunya akan tumbuh keingintahuan untuk menyaksikan secara langsung pementasan wayang potehi.

\section{SIMPULAN}

Berdasarkan uraian hasil dan pembahasan secara umum, dapat disimpulkan bahwa wayang potehi merupakan tradisi lisan yang didukung oleh berbagai aspek pementasan seperti, (a) situasi dan tempat pementasan, (b) dalang, (c) penonton, (d) peralatan (alat musik dan kostum), dan (e) variasi pementasan sebagai akibat dari respon penonton. Berkaitan dengan proses produksi lakon pementasan wayang potehi, peneliti menemukan ada berbagai bentuk stock in trade yang terdapat dalam lakon Sam Hee Lam Tong dan Sie Djin Koei Tjeng See, yaitu (a) formula epitheton (tokoh dan benda), (b) ungkapan formulaik, dan (c) tema/kumpulan gagasan. Terdapat lima fungsi yang dimiliki oleh wayang potehi, yaitu (a) fungsi ritual, (b) fungsi hiburan, (c) fungsi pendidikan, (d) fungsi sosial, (e) fungsi ekonomi. Bentuk pewarisan wayang potehi juga dapat dilakukan dengan banyak cara. (a) Para dalang aktif melakukan kaderisasi baik di dalam rumah tangganya atau saat pementasan kepada dalang muda dengan menggunakan formula lakon wayang potehi secara sadar. Dengan menguasai formula maka calon dalang akan dengan mudah memahami dan mengingat lakon 
meskipun cukup panjang. (b) Keterlibatan pemerintah secara lebih maksimal untuk mentradisikan wayang potehi serta menggerakkan dinas-dinas terkait untuk secara intens mendorong dan mendampingi pengembangan wayang potehi. (c) Hal lain yang dapat dilakukan oleh pemerintah ialah mengadakan kaderisasi/ peningkatan profesionalisme dalang. (d) Festival wayang potehi dalam skala nasional pun bisa menjadi alternatif yang baik, mengingat wayang potehi belum pernah difestivalkan secara khusus. (e) Perlu mendirikan komunitas/paguyuban yang dapat menjadi tempat berbagai para dalang, kaderisasi dalang muda, serta bendera untuk memperjuangkan hak-hak dalang. (f) Inovasi terhadap wayang potehi juga bisa menjadi alternatif lainnya. Apalagi saat ini wayang potehi berhadapan dengan media-media mainstream yang banyak digemari masyarakat. Pementasan wayang potehi pun dapat dikemas dalam bentuk compact disc (CD) atau softfile yang dapat digunakan sebagai media pembelajaran.

Memaknai wayang potehi berarti mengenalinya lebih jauh dan dapat melihat eksistensinya di tengah rongrongan banyak kebudayaan luar. Sudah sepantasnya kita kembali menghidupkan wayang potehi sebagai bagian dari kebudayaan Nusantara dan menjadikannya sebagai media alternatif transfer nilai-nilai budi pekerti. Pemerintah, masyarakat, dan para pegiat potehi perlu bersinergi dan memiliki keprihatinan yang sama terhadap persoalan ini. Dengan mengupayakan banyak langkah nyata, wayang potehi dapat kembali berjaya seperti dulu.

\section{UCAPAN TERIMA KASIH}

Arikel ini merupakan bagian dari disertasi pada Program Studi S-3 IlmuIlmu Humaniora, Fakultas Ilmu Budaya, Universitas Gadja Mada yang telah dipertanggungjawabkan dalam sidang tertutup dan dinyatakan lulus. Oleh karena itu, pada bagian ini penulis ingin mengucapkan rasa terima kasih kepada (a) Prof. Dr. Heddy Shri Ahimsaputra, M.A.,M.Phil. selaku promotor; (b) Dr. G.R. Lono Lastoro Simatupang, M.A. selaku ko-promotor; (c) seluruh jajaran Universitas; dan (d) Dr. Pudentia Maria Purenti Sri Sunarti, M.A. selaku Ketua Asosiasi Tradisi Lisan yang telah memberikan dukungan moril.

\section{DAFTAR PUSTAKA}

Baal, J. van. 1988. Sejarah dan Pertumbuhan Teori Antropologi Budaya (Hingga Dekade 1970) Jilid 2. Jakarta: Gramedia.

Dwirahmi, Anastasia. 2010. "Bukan Sekadar Potehi". (Daring) https:// anastasiadwirahmi.wordpress.com/ category/peranakan. Diakses pada 16 April 2017 pkl 10.00 WIB.

Finnegan, Ruth. 1992. Oral Tradition and The Verbal Arts: A Guide to Research Practices. London: Routledge.

Insriani Hesti. 2014. "Modal dan Makna Kerja Dalang Wayang Potehi di Semarang Kisah Hidup Thio Tiong Gie". Tesis. Yogyakarta: FIB UGM.

Koentjaraningrat 1987. Sejarah Teori Antropologi I. Jakarta: UI-Press.

Lestari, Ngesti. 2010. Dari Wayang Potehi Ke Wayang Thithi: Suatu Kajian Historis Seni Pertunjukan Wayang Potehi di Semarang dan Perkembangannya. Semarang: Jurusan Sejarah Universitas Diponegoro.

Lord, Albert B.. 1976. The Singer of Tales. Harvard University Press.

Maskurin, Sunariyadi dan Septina Alrianingrum. 2014. "Perkembangan Wayang Potehi di Surabaya Tahun 1967-2001" dalam e-Jurnal Pendidikan Sejarah Avatara, Vol. 2 No. 3 Oktober 2014, hal. 169-182.

Mastuti dkk. 2009. Wayang Potehi dan Wayang Kulit Cina-Jawa: Katalogisasi, Makna, dan Fungsi sebagai Wujud Bela Negara Non-Militer. Hibah Kompetitif Penelitian sesuai Prioritas Nasional (Dikti) Tahap I. 
Prawita, Astri. 2013. “Eksistensi Wayang Potehi di Jakarta". (On line). http:// lib.ui.ac.id/file?file=digital/2015-8 /20392780-MK-Astri\%20Prawita.pdf. Diakses Selasa, 7 Januari 2017, pkl 00.00 WIB.

Sunarti dan Pudentia MPSS. 2007. Hakikat Kelisanan dalan Tradisi Lisan Melayu Mak Yong. Depok FIPB UII.

Sutrisno. 1950. “Siu Lam Pek”. Ditulis untuk kepentingan pementasan wayang potehi.

Soetrisno, Eddy. 1968. "Sam Hee Lam Tong". Ditulis untuk kepentingan pementasan Wayang Potehi.

Taum, Yoseph Yapi. 2011. Studi Sastra Lisan Sejarah Teori, Metode, dan Pendekatan Disertai Contoh Penerapannya. Yogyakarta: Lamalera.

Udu, Sumiman. 2016. Tradisi Bhantibhanti Wakatobi: Pementasan, Formula dan Komposisi Skematiknya (Disertasi). Yogyakarta: Program Pascasarjana Fakultas Ilmu Budaya Universitas Gadjah Mada.

Vansina, Jan. 1973. Oral Tradition. Australia: Penguin University.
Waluyo, Sugiyo. 2001. “Sie Djin Koei Tjeng See". Dibuat untuk kepentingan pementasan Wayang Potehi.

\section{CATATAN}

${ }^{1}$ Dalang Thio Tiong Gie yang memiliki nama lain Teguh Candra Irawan ini berdomisili di kampung Pesantren, Jl. Petudungan, No. 326, Semarang wafat dengan meninggalkan 7 anak, $23 \mathrm{cucu}$, dan 1 cicit. Ketujuh anak Thio Tiong Gie adalah Thio Koei Lian, Thio Haouw Poen, Thio Koei Hwa, Thio Haouw Lip, Thio Haouw Lie, Thio Koei Hoen, dan Thio Haouw Too. Istrinya telah wafat 25 tahun sebelumnya.

${ }^{2}$ Disampaikan dalam wawancara pada 21 November 2016.

${ }^{3}$ eprints.undip.ac.id/../Melacak_sejarah_ Pecinan_melalui_Toponim

${ }^{4}$ Disampaikan dalam wawancara pada 6 November 2016.

${ }^{5}$ Disampaikan dalam wawancara pada 13 Agustus 2016.

${ }^{6}$ Disampaikan dalam wawancara pada 18 Januari 2017. 